\title{
A STUDY OF SUSCEPTIBILITY AND EVALUATION OF CAUSES OF CRACKS FORMATION IN BRAZE-WELD FILLER METAL IN LAP JOINTS ALUMINUM - CARBON STEEL MADE WITH USE OF CMT METHOD AND HIGH POWER DIODE LASER
}

\begin{abstract}
In this article results of studies on cracks formation susceptibility in braze-welded joints of thin aluminum sheets and doublesided zinc galvanized steel sheets for car body parts made by laser brazing with high power diode laser ROFIN DL 020 and CMT MIG-brazing, with filler material in form of powder and wire accordingly, were presented. Optimal welding parameters were determined by visual acceptance criteria. On joints made with optimal parameters further examinations were carried. Results of macro- and microscopic metallographic examinations, structural roentgenography, EDS microanalysis and hardness tests were presented. Causes of brittle intermetallic Fe-Al phases formation in Al-matrix filler metal in dissimilar aluminum - zinc plated carbon steel joints were pointed.
\end{abstract}

Keywords: Braze-welding, Intermetallic compound phase, high power diode laser, brazing

\section{Introduction}

Contemporary auto bodies must not only be ecstatically pleasing, but most of all conform to latest safety regulations, durability, comfort and low production cost requirements. Currently automotive manufacturers strongly compete in this areas, by applying innovative construction solutions, use of stronger steel grades (from High Strength Steel (HSS) to advanced nanostructural steels with very high strength steel of $3^{\text {rd }}$ generations AHSS, (Fig. 1a), Introduction of new fabrication methods of car body elements (e.g. tailored blank and tailor rolled blanks) as well as use of hi-tech joining methods like: adhesive bonding, friction welding, low-energy MIG-brazing or laser welding, both conventional and hybrid [1-7]. Important aim during design of new generation vehicles is most of all reduction of weight. It translates to higher performance and lower exploitation cost.

This aims are obtained by increasing thickness of steel sheets on elements most prone to destruction during car crash (e.g. B pillars and front doors) and joining with welding methods elements press from galvanized steel and aluminum sheets, Fig. 1b. High capabilities of joining this types of materials are enable by braze-welding, especially when used with low solidus - liquidus temperature range, e.g. Zn-Al4 $\left(385-418^{\circ} \mathrm{C}\right)$ or AlSi12 $\left(573-585^{\circ} \mathrm{C}\right)$. However, substantial problem in this type of joints are cracks frequently occurring in braze filler metal near protective zinc layer on steel sheet [7-9]. a

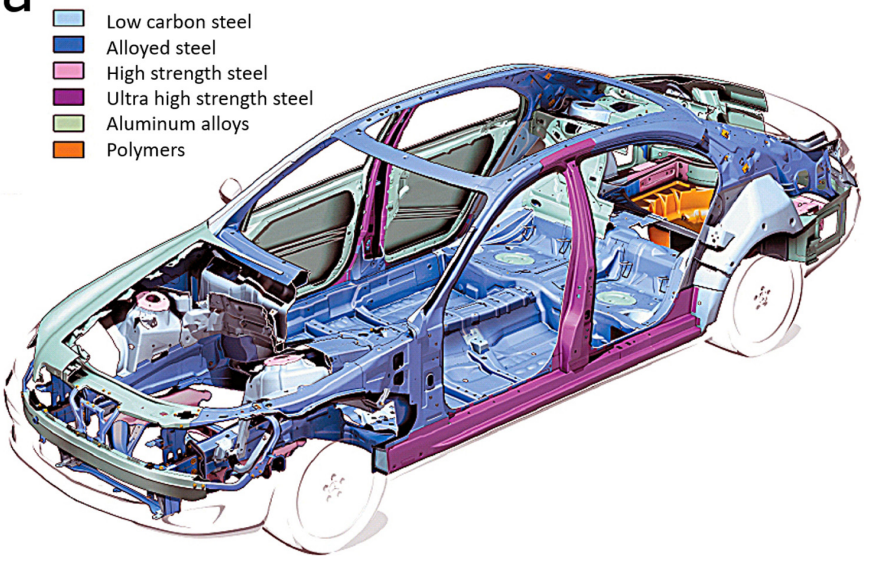

b

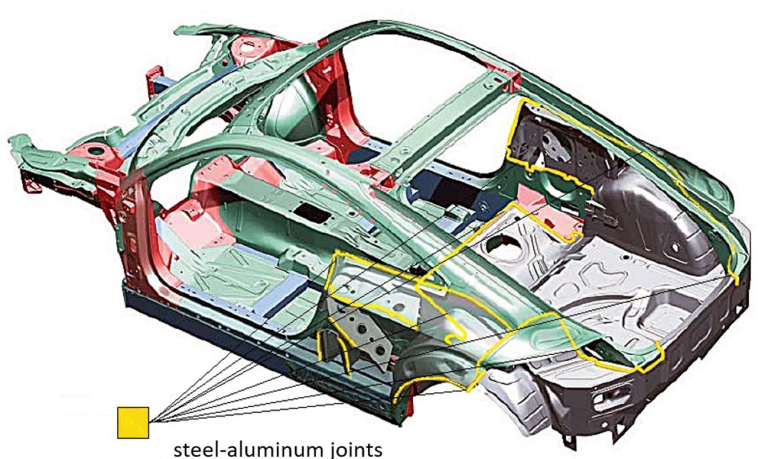

Fig. 1. Overview of car body: a) materials used for building automotive body, b) locations of steel - aluminium joints in car chassis

* $\quad$ SILESIAN UNIVERSITY OF TECHNOLOGY, 18A, KONARSKIEGO STR.,44-100 GLIWICE, POLAND
* Corresponding author: marcin.adamiak@polsl.pl 


\section{Experimental procedure and materials}

Carried examinations were targeted at determining weldbrazed joint formation and factors promoting brittle cracking of dissimilar weld-brazed joints of thin aluminum sheets and double side galvanized carbon steel made by high power diode laser with filler metal in form of powder and CMT MIG-brazing with filler metal in form of solid wire. Based on visual examinations and macroscopic metallographic examinations braze-welded joint shape and quality were assessed. Precise microscopic metallographic examinations, structural roentgenography and EDS microanalysis enabled assessment of filler metal and base metal structure, as well as, evaluation of possible factors promoting formation of brittle intermetallic phases in dissimilar braze-welded aluminum - zinc plated carbon steel joints. Test joints were made on mechanized welding rig with cross table with linear guide and clamping fixing weld-brazed plates and according to carried examinations either high power diode laser ROFIN DL 020 with plate powder feeder or TransPuls Synergic 3200 CMT MV R with equipment. During laser brazing laser head was perpendicular to table surface, with laser spot placed as shown in Fig. 2a. Aluminum powder feeding nozzle was placed $45^{\circ}$ to surface of joined plates and in way enabling feeding of brazing filler metal in joint axis. CMT MIG-brazing was carried with direct current with positive polarity with flat position, in right direction, torch angle to sheet surface was $90^{\circ}$ and arc was placed over aluminum sheet, Fig. $2 b$.

For lap joints welding of thin plates with dimensions $1.0 \times 150 \times 100 \mathrm{~mm}$ made from soft carbon steel for direct plastic working grade DC04+ZE75/ZE75 (acc. EN ISO 10152:2-11) galvanized for both side with zinc plating $7.5 \mu \mathrm{m}$ and plates with dimensions $2.0 \times 150 \times 100 \mathrm{~mm}$ made from aluminum grade $1050 \mathrm{~A}$ (acc. EN 573-3:2014) were used. Chemical composition and mechanical properties of braze-welded materials are presented in Table 1 and Table 2.

TABLE 1

Content of alloying elements and mechanical properties of soft steel plate for direct plastic working grade DC04+ZE75/75 zinc galvanized from both sides

\begin{tabular}{|c|c|c|c|}
\hline \hline \multicolumn{4}{|c|}{ Chemical composition[\%] } \\
\hline $\mathbf{C}$ & $\mathbf{M n}$ & $\mathbf{P}$ & $\mathbf{S}$ \\
\hline$<0,08$ & $<0,40$ & $<0,03$ & $<0,03$ \\
\hline \multicolumn{4}{|c|}{ Mechanical properties } \\
\hline $\boldsymbol{R}_{\boldsymbol{e}}[\mathrm{MPa}]$ & $\boldsymbol{R}_{\boldsymbol{m}}$ min. $[\mathbf{M P a}]$ & $\boldsymbol{A}_{\mathbf{5}}$ min. $[\%]$ & Zinc layer, $[\boldsymbol{\mu m}]$ \\
\hline $140 \div 220$ & $270 \div 350$ & 38 & 7,5 \\
\hline
\end{tabular}

TABLE 2

Content of alloying elements and mechanical properties of aluminium plate grade 1050A (acc. EN ISO 573-3:2014)

\begin{tabular}{|c|c|c|c|c|c|c|c|c|}
\hline \hline \multicolumn{10}{|c|}{ Chemical composition [\%] } \\
\hline $\mathbf{A l}$ & $\mathbf{F e}$ & $\mathbf{S i}$ & $\mathbf{Z n}$ & $\mathbf{T i}$ & $\mathbf{M g}$ & $\mathbf{M n}$ & $\mathbf{C u}$ & other \\
\hline 99,5 & $<0,4$ & $<0,25$ & $<0,07$ & $<0,05$ & $<0,05$ & $<0,05$ & $<0,05$ & $<0,03$ \\
\hline \multicolumn{8}{|c|}{ Mechanical properties } \\
\hline \multicolumn{8}{|c|}{$\boldsymbol{R}_{\boldsymbol{e}}[\mathbf{M P a}]$} & \multicolumn{6}{c|}{$\boldsymbol{R}_{\boldsymbol{m}}$ min. [MPa] } & \multicolumn{5}{c|}{$\boldsymbol{A}_{\mathbf{5}}$ min. [\%] } \\
\hline \multicolumn{3}{|c|}{$65 \div 95$} & \multicolumn{5}{c|}{26} \\
\hline
\end{tabular}

Laser brazing tests were carried with use of additional material in form of aluminum grade 1070A powder (acc. EN 573-3:2014) with particle size of $450 \mu \mathrm{m}$ (Table 3). Filler metal with such composition is used in joining processes in chemical, food, electronics and construction industries.
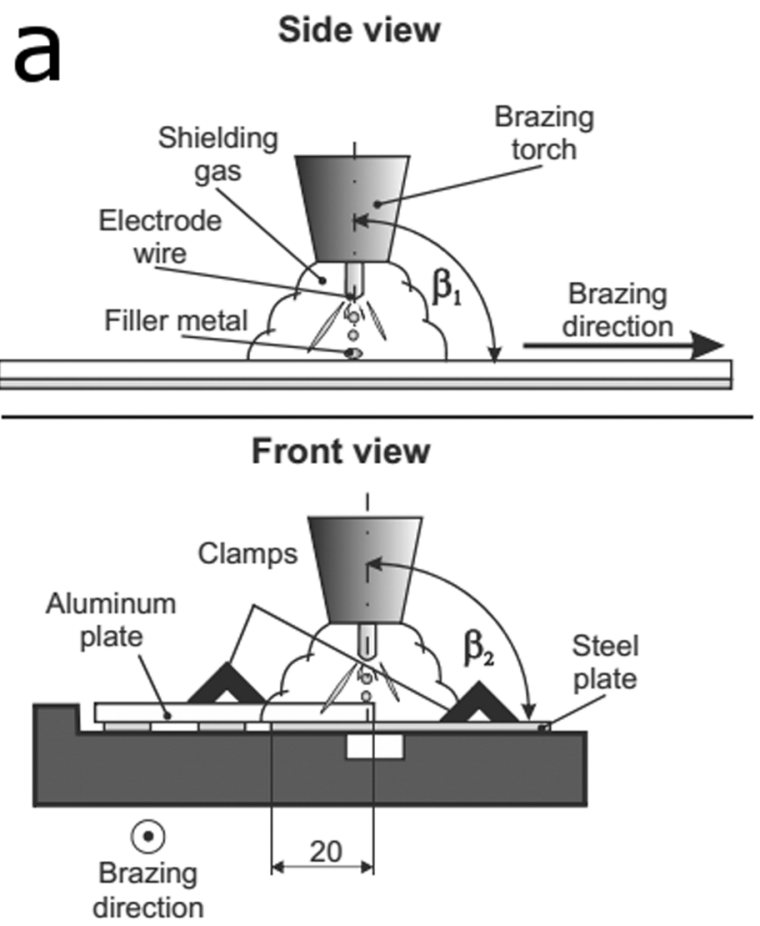

b
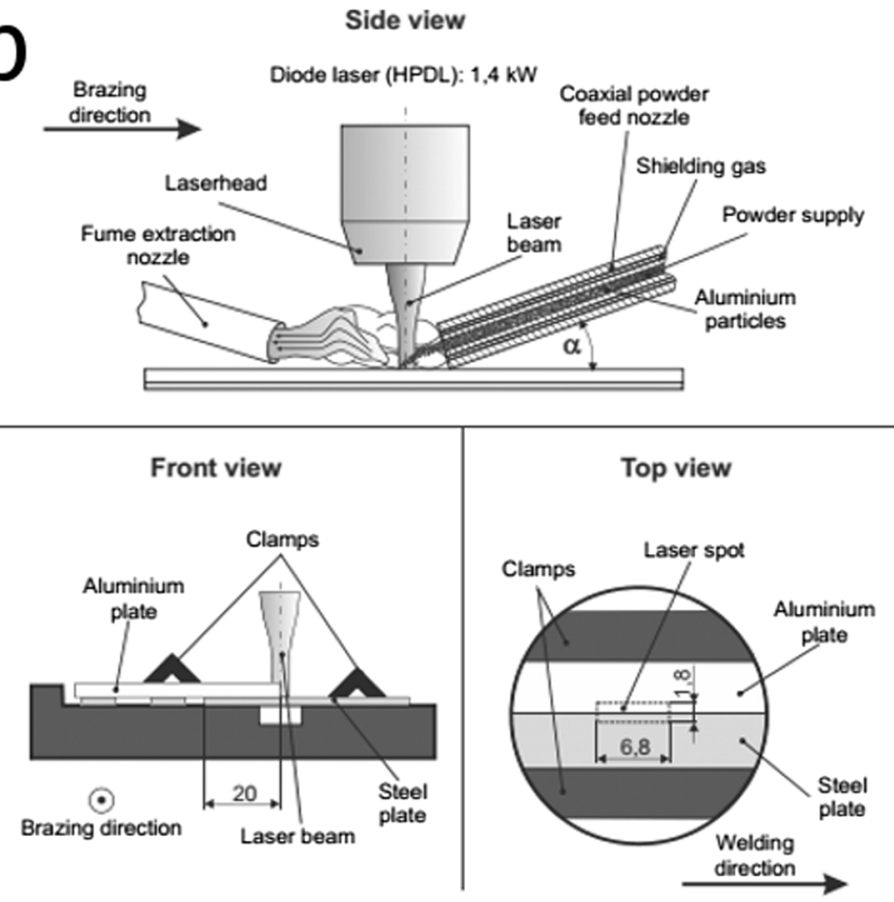

Fig. 2. Means of fixture and heat source configuration in experimental rig for mechanized braze-welding during: a) high power diode laser (HPDL) braze-welding with additional material in form of powder, b) CMT MIG-brazing with additional material in form of wire 
Content of alloying elements of aluminium powder grade 1070A (acc. PN-EN 573-3:2014)

\begin{tabular}{|c|c|c|c|c|c|c|c|}
\hline \hline \multicolumn{7}{|c|}{ Chemical composition [\%] } \\
\hline $\mathbf{A l}$ & $\mathbf{S i}$ & $\mathbf{Z n}$ & $\mathbf{F e}$ & $\mathbf{T i}$ & $\mathbf{C u}$ & $\mathbf{M n}$ & $\mathbf{M g}$ \\
\hline$>99,70$ & $<0,20$ & $<0,07$ & $<0,25$ & $<0,03$ & $<0,03$ & $<0,03$ & $<0,03$ \\
\hline
\end{tabular}

Additional material for CMT MIG-brazing was in form of solid wire grade S AL 4047 (AlSi12) - acc. To EN ISO 18273:2016 (Table 4). AlSi12 additional metal is used mainly for repairing aluminum alloy castings containing 7-12\% $\mathrm{Si}$ e.g. G-AlSi12, G-AlSi8Cu3, G-AlMg3Si and others. This alloy is also suitable for joining different aluminum alloys, especially for alloys prone to hot cracking and for making aluminum construction working in high temperature environments. It is used in joining with welding methods of automotive parts and in HVAC industry. Before brazing test joints joined elements were placed on table fitted with clamping equipment. On each try aluminum plate was placed over steel plate using overlap of $20 \mathrm{~mm}$. Optimal parameters of powder laser brazing and CMT MIG-brazing, that enable formation of dissimilar lap joints between thin aluminum plates grade 1050A and carbon steel grade DC04 galvanically zinc plated from both sides are presented in Table 5 and Table 6.

TABLE 4

Contents of alloying elements and mechanical properties of additional material in form of solid wire 1,2 mm in diameter, grade S Al 4047 (AlSi12) (acc. EN ISO 18273:2016)

\begin{tabular}{|c|c|c|c|c|}
\hline \hline \multicolumn{5}{|c|}{ Chemical composition [\%] } \\
\hline $\mathbf{A l}$ & $\mathbf{S i}$ & $\mathbf{F e}$ & $\mathbf{M n}$ & $\mathbf{Z n}$ \\
\hline reszta & 12,0 & $<0,60$ & $<0,15$ & $<0,20$ \\
\hline \multicolumn{5}{|c|}{ Mechanical properties } \\
\hline $\boldsymbol{R}_{\boldsymbol{p 0 , 2}}[\mathbf{M P a}]$ & $\boldsymbol{R}_{\boldsymbol{m}}$ min. [MPa] & \multicolumn{3}{|c|}{$\boldsymbol{A}_{\mathbf{5}}$ min. [\%] } \\
\hline 80 & \multicolumn{2}{|c|}{170} & \multicolumn{2}{|c|}{12} \\
\hline
\end{tabular}

TABLE 5

Optimal technological parameters enabling formation of dissimilar thin plate lap joints by high power diode laser braze-welding made of aluminium grade 1050A and carbon steel DC04 zinc galvanized from

both side with use of additional material in form of grade 1070A aluminium powder

\begin{tabular}{|c|c|c|c|c|c|}
\hline $\begin{array}{c}\text { Output } \\
\text { power } \\
P \\
{[W]}\end{array}$ & \begin{tabular}{|c|} 
Brazing \\
speed \\
$V_{s p}$ \\
{$[\mathrm{~m} / \mathrm{min}]$}
\end{tabular} & \begin{tabular}{|c|} 
Powder \\
feed rate \\
$V$ \\
{$[\mathrm{~g} / \mathrm{min}]$} \\
\end{tabular} & \begin{tabular}{|c|} 
Shielding \\
gas flow rate \\
$\underset{\left[\mathrm{dm}^{3} / \mathrm{min}\right]}{Q}$ \\
\end{tabular} & \begin{tabular}{|c|} 
Chemical \\
composition \\
of shielding \\
gas
\end{tabular} & $\begin{array}{c}\text { Powder } \\
\text { feeding } \\
\text { nozle angle } \\
\alpha\left[^{\circ}\right]\end{array}$ \\
\hline 1400 & 0,2 & 1,0 & 2,5 & $100 \% \mathrm{Ar}$ & 45 \\
\hline
\end{tabular}

\section{Results and discussion}

After braze-welding visual tests on joints between thin aluminum plates grade 1050A and carbon steel grade DC04 were carried. Visual examinations were proceeded in conditions described in EN ISO 17637:2011. Examination results of joints made with use of high power diode laser and additional
Optimal technological parameters enabling formation of dissimilar thin plate lap joints by high power diode laser braze-welding made of aluminium grade 1050A and carbon steel DC04 zinc galvanized from both side with use of additional material in form of S Al 4047 solid wire

\begin{tabular}{|c|c|c|c|c|c|c|}
\hline $\begin{array}{c}\text { Arc } \\
\text { current } \\
I \\
{[A]}\end{array}$ & $\begin{array}{c}\text { Arc } \\
\text { voltage } \\
U \\
{[\mathrm{~V}]}\end{array}$ & $\begin{array}{c}\text { Brazing } \\
\text { speed } \\
V_{s p} \\
{[\mathrm{~cm} / \mathrm{min}]}\end{array}$ & $\begin{array}{c}\text { Wire } \\
\text { feed rate } \\
V_{d} \\
{[\mathrm{~m} / \mathrm{min}]}\end{array}$ & $\begin{array}{l}\text { Shielding } \\
\text { gas flow } \\
\text { rate } \\
Q \\
{\left[\mathrm{dm}^{3} / \mathrm{min}\right]}\end{array}$ & $\begin{array}{c}\text { Chemical } \\
\text { composition } \\
\text { of shielding } \\
\text { gas }\end{array}$ & $\begin{array}{c}\text { Torch } \\
\text { angle } \\
B_{1} / \beta_{2} \\
{\left[{ }^{\circ}\right]}\end{array}$ \\
\hline 78 & 12,4 & 45 & 4,5 & 12 & $100 \% \mathrm{Ar}$ & $90 / 90$ \\
\hline
\end{tabular}

material in form of powder as well as joints made with use of CMT arc-brazing with additional material in form of wire have shown correct spreadability and formation of filler metal, which in both cases covered steel plate adequately to requirements. Braze-welded joints have possessed regular geometry, correct dimensions, metallic shine and smooth face. On the back side of braze-welded joints, on steel plate surface in place near heat source path, no deterioration of corrosion protective layer was observed. In joints no defects such as surface cracks, cold lapping or insufficient fill were observed.

Metallographic examinations in macro- and microscopic scale were carried in order to evaluate joint structure and to reveal potential internal defects in braze-welded joints. Microscopic examinations were carried on etched specimens of weld-brazed joints traverse cross-sections. Preliminary examinations of braze-welded joints cross-sections in macro scale were made with use of stereoscopic microscope with magnification from 4 to 25 times. Additional metallographic examinations were carried with use of light microscope in distinctive joint areas, with magnification from 100 to 800 times. Photographs of macrostructure with microstructural views of base materials, filler metal, HAZ, transition line between base materials and filler metal were presented in Figs. 3-4.

Based on joint cross-section metallographic photographs microstructures of base materials were established. Aluminum grade $1050 \mathrm{~A}$ had $\alpha$-Al structure with certain amount of peritectic and carbon steel grade DC04 had small-grained ferritic structure with traces of perlite. Between joint made by different brazing method, major structural differences in filler metal were observed. In joint made by laser brazing with additional material in from of metallic powder correct cross-section geometry, with set amount of longitudinal gas pores, was observed, Fig. 3a. Additionally, in filler metal acicular inclusions starring at and perpendicular to steel plate surface (Fig. 3d), as well as, band inclusions parallel to transition line from filler metal to carbon steel (Fig. 3b and c) were identified. Moreover, a crack in filler metal placed just above steel plate surface was pointed out. In base material, under protective zinc layer, thin HAZ was observed. In joint made by CMT MIG-brazing regular shape of cross-section was observed, however singular nearly circular gas pores were noted (Fig. 4a). Filler metal structure is characterized by dendritic precipitations of $\alpha$-Al solid solution surrounded by fine-grained eutectic. Transition line between filler metal 

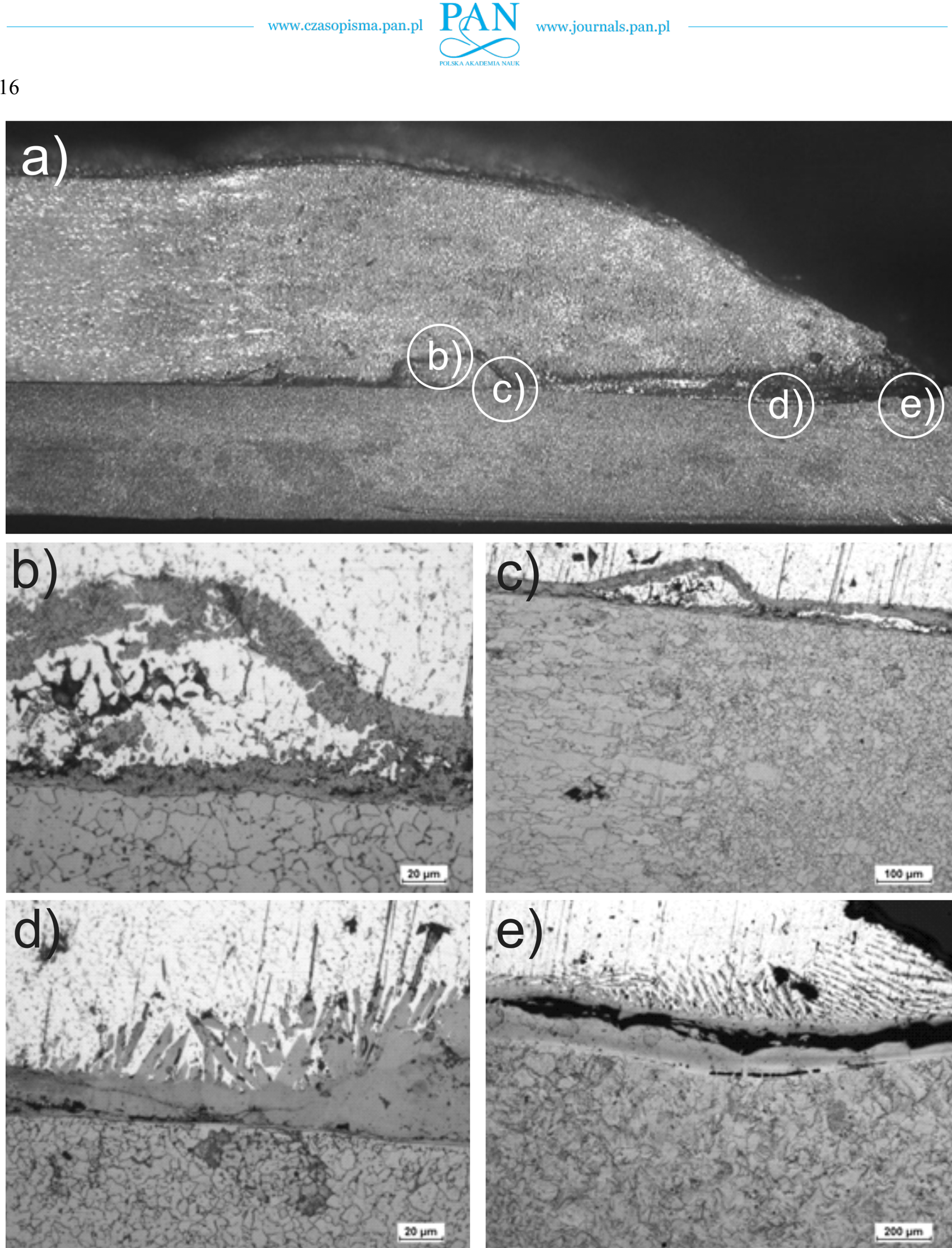

Fig. 3. View of macro- and microstructure of sample cut from dissimilar lap joint aluminium grade 1050A - galvanized carbon steel DC04 brazewelded by high power diode laser with additional material in form of grade 1070A aluminium powder (aluminium in the top, steel in the bottom): a) joint macrostructure; b), c), d), e) braze metal - galvanized carbon steel plate contact area microstructure

and aluminum plate was regular with minimal fusion into base material (Fig. 4c). On phase border between galvanized steel aluminum filler metal dissolvement of zinc layer with nearly no fusion into steel plate was noted (Fig 4d).

For acquisition of high quality structural views of brazewelded joints scanning electron microscope was used. Observa- tion of specimens were carried under magnification from 500 to 10000 times. Obtained results enabled to specify chemical composition in microareas in which cracks were observed, check chemical composition of unidentified inclusions in filler metal and identification of other defects such as: gas voids, cracks and others. Sample results of inclusions observations and microanaly- 

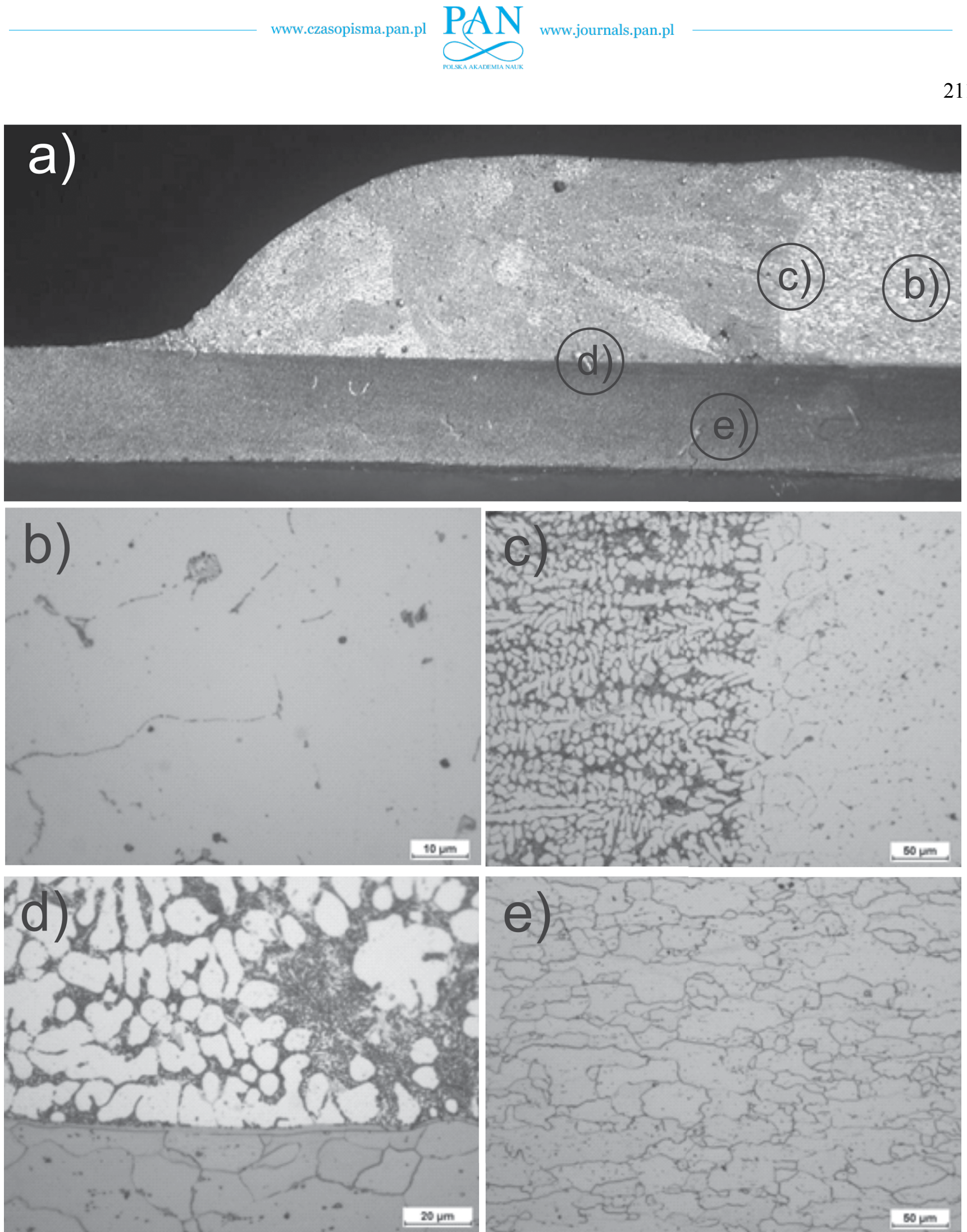

Fig. 4. View of macro- and microstructure of sample cut from dissimilar lap joint aluminium grade 1050A - galvanized carbon steel DC04 CMT MIG-brazed with additional material in form of grade S Al 4047 solid wire (aluminium in the top, steel in the bottom): a) joint macrostructure, b) $\mathrm{Al}$ 1050A parent metal microstructure, c) braze metal - Al 1050A parent metal transition area microstructure, d) braze metal - galvanized carbon steel plate contact area microstructure e) galvanized steel DC04 parent material microstructure

sis of their chemical composition were shown in Figs. 5 and 6.

In band inclusions, localized in filler metal over the surface of steel plate iron content up to $43 \%$ was observed. Cause of iron content appearance in aluminum filler metal were melting of zinc layer and partial fusion into steel plate. Chemical composition microanalysis of joint made by use of CMT MIG- brazing in area corresponding to location of band inclusion in laser brazed joint has shown no iron content. However, in filler metal small inclusions with complex chemical composition were noted (Fig. 6).

In Fig. $7 \mathrm{SEM}$ view of filler metal outer edge located near steel plate surface $\left(\mathrm{Zn}_{1}-\right.$ Fig. 8$)$, from laser brazed joint with 

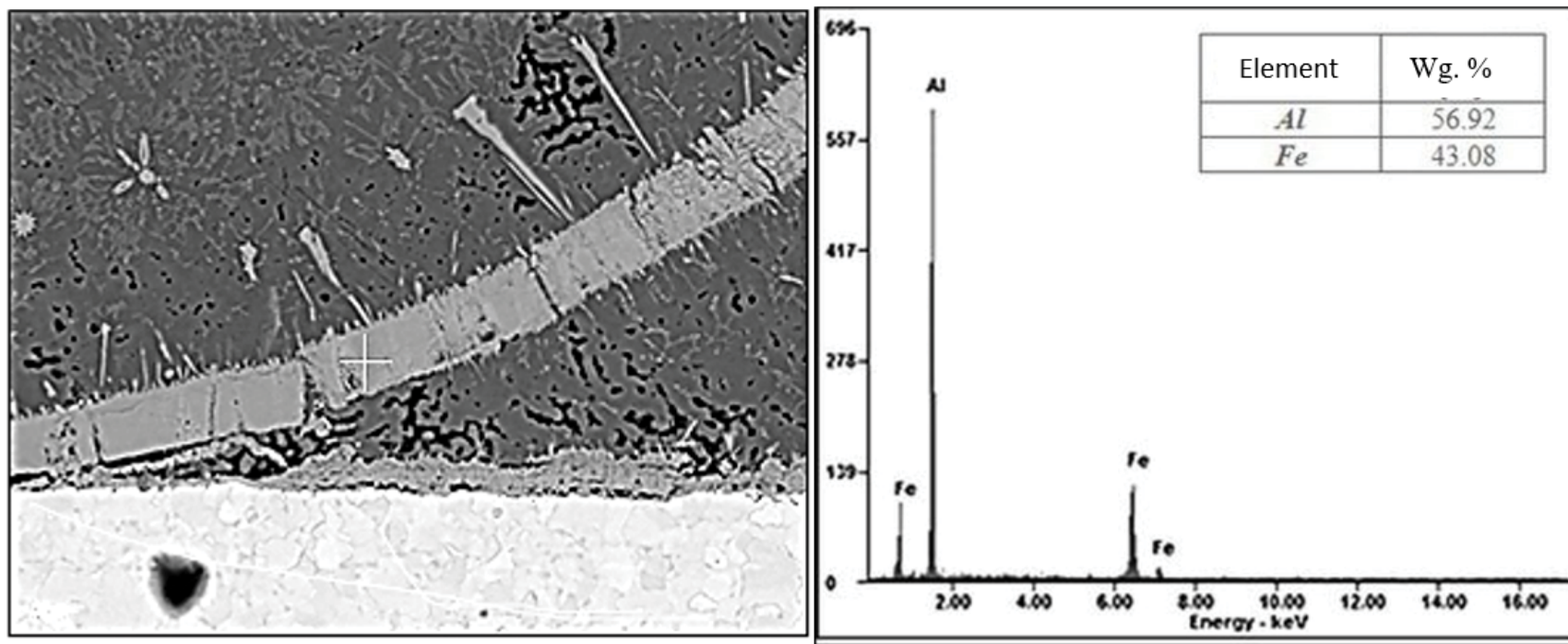

Fig. 5. SEM view of inclusions in braze metal of lap joint aluminium grade 1050A - galvanized carbon steel DC04 braze-welded by high power diode laser with additional material in form of grade 1070A aluminium powder (magn. 1000×) and micro-analysis of chemical composition in test point located on inclusion in braze metal
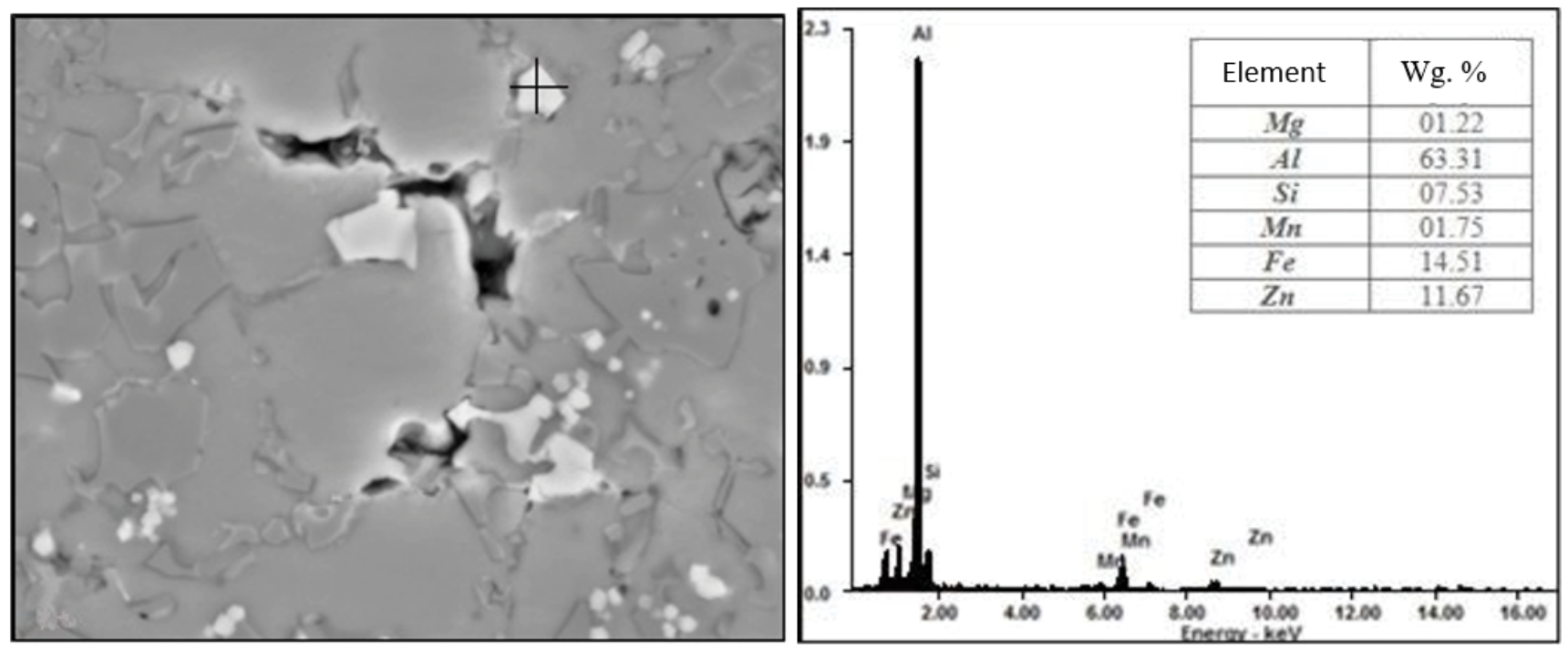

Fig. 6. SEM view of inclusions in braze metal of lap joint aluminium grade 1050A - galvanized carbon steel DC04 CMT MIG-brazed with additional material in form of grade S Al 4047 solid wire (magn. 5000×) and micro-analysis of chemical composition in test point located on inclusion in braze metal

additional material in form of powder specimen, was presented. In this area no increased zinc content was noted and observed microstructure was composed from $\mathrm{Al}-\mathrm{Fe}$ intermetallic phases and aluminum with small iron content located between $\mathrm{Al}-\mathrm{Fe}$ needles. In this joint however zinc rich area was located near fusion line into aluminum plate and filler metal - steel plate border $\left(\mathrm{Zn}_{2}-\right.$ Fig. 8). In this area zinc was dissolved up to $0,3 \mathrm{~mm}$ into aluminum filler metal, additionally gas pores were observed there (Fig. 9). Zinc content in analyzed microarea was $12.7 \%$.

In case of joint braze-welded with CMT MIG-brazing high zinc content, over $27 \%$, was observed on outer edge of filler metal (Fig. 10). Significant zinc amount was only found in this triangularly shape area near outer edge of filler metal near steel plate surface $\left(\mathrm{Zn}_{1}\right)$. Height of this triangle was about $0.25 \mathrm{~mm}$ and its base was $1 \mathrm{~mm}$.
Different placement of zinc rich areas in filler metal between joints made by laser brazing and MIG-brazing can be caused by one or more of following factors: direction and velocity of molten metal convection movements, heat source energy density level, process thermal cycle, filler metal solidification conditions.

Energy-dispersive X-ray spectroscopy (EDS) microanalysis enabled thickness measurement, as well as, spot, linear and surface chemical composition determination of reactive layer between steel plate and aluminum matrix filler metal. Moreover, chemical composition of filler metal was tested. EDS results were presented in Figs. 11-12.

In laser brazed joint with filler metal in form of powder reactive layer thickness was between 20 and $300 \mu \mathrm{m}$ and increased with distance from fusion line into aluminum plate (Fig. 11). 


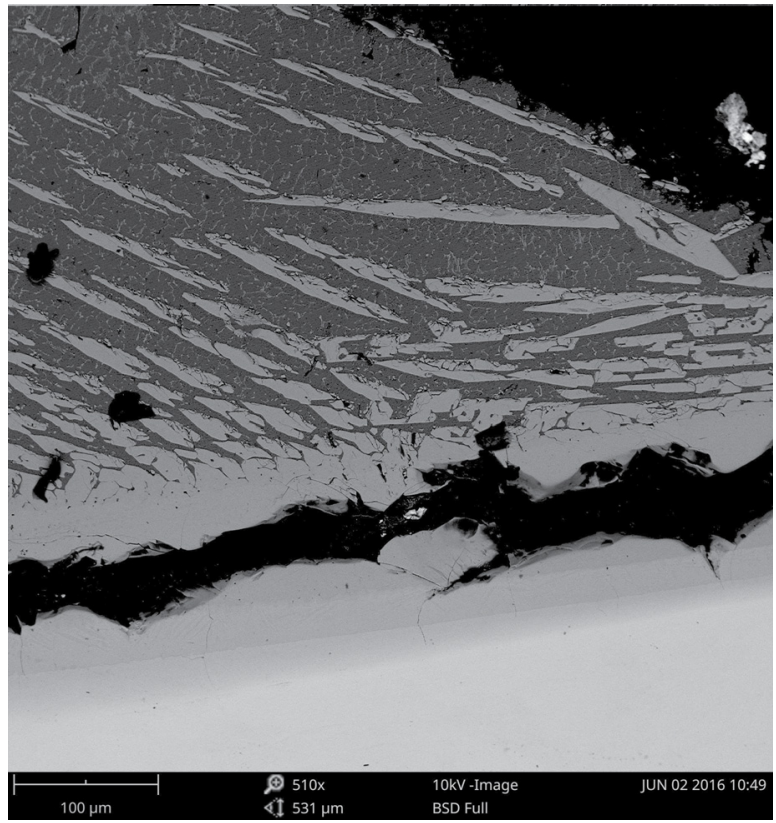

Fig. 7. BSE view of braze metal side of lap joint aluminium grade 1050A - galvanized carbon steel DC04 braze-welded by high power diode laser with additional material in form of grade 1070A aluminium powder

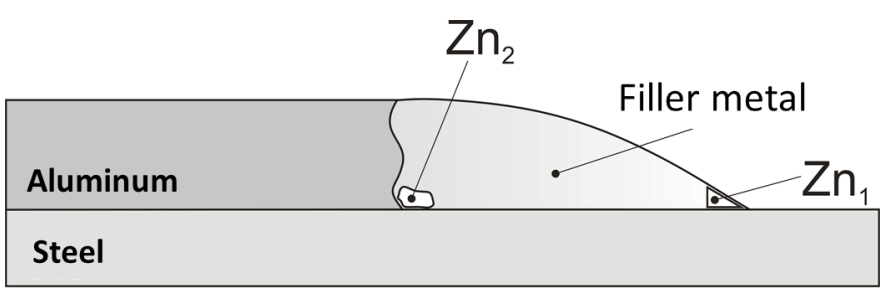

Fig. 8. Areas of increased zinc content in aluminium matrix brazewelded joint
Reactive layer possessed many defects in form of cracks and discontinuities propagating along border with steel plate and was composed mainly from mixture of Al-Fe intermetallic phases. It was validated by microanalysis in area 2 (Fig. 11), that has shown content of over $46 \%$ Fe and just under $54 \%$ of Al. Linear EDS analysis made along path 3 (Fig. 11) have shown uniformity of chemical composition in Fe-Al layer, aside from 2 point where content of aluminum raised sharply on short sections. In these places on Back Scattered Electron view small discontinuities filled with aluminum matrix alloy in reactive layer were observed. Several other discontinuities were observed on elemental heat maps for $\mathrm{Fe}$ and $\mathrm{Al}$ (Fig. 12). In microarea 1 located outside of reactive layer chemical composition analysis has shown presence of iron in filler metal in amount of about $2 \%$, which is according to solubility of iron in liquid aluminum in temperatures just above melting point of pure $\mathrm{Al}$.

In CMT MIG-brazed joint reactive layer was continuous, uniform and well adhered to steel plate surface. Thickness of this layer was varying insignificantly and was contained between 4 and $8 \mu \mathrm{m}$. Spot analysis of filler metal performed in short distance from transition layer (point 1, Fig. 13), in comparison to chemical composition of additional material, has shown high aluminum content $(99.1 \%)$ and low silicon content ( $0.9 \%)$. EDS spot analysis was carried in middle of reactive layer thickens (point 2, Fig. 13a) and have shown content of around 54\% aluminum, 36\% iron and just under 10\% silicon. Chemical composition of reactive layer on its thickness was verified by EDS linear scan along path 3 (Fig. 13). The chemical composition of transition layer was uniform, but sharp increase of silicon content near transition point from filler metal into reactive layer was observed. To further analyze silicon content variations in filler

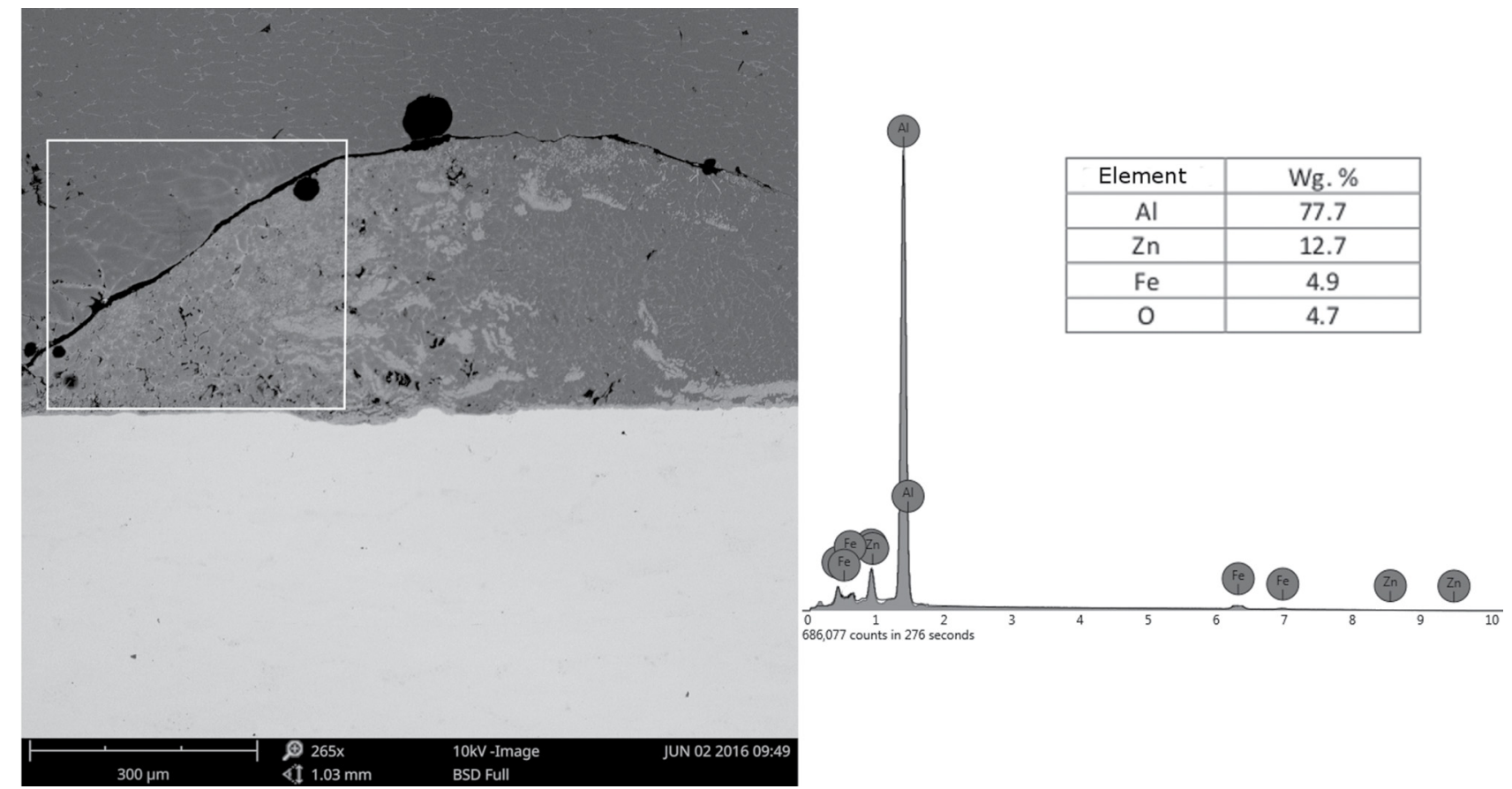

Fig. 9. BSE view of zinc-rich area in braze metal of lap joint aluminium grade 1050A - galvanized carbon steel DC04 braze-welded by high power diode laser with additional material in form of grade 1070A aluminium powder and micro-analysis of chemical composition in test area located near steel plate surface 

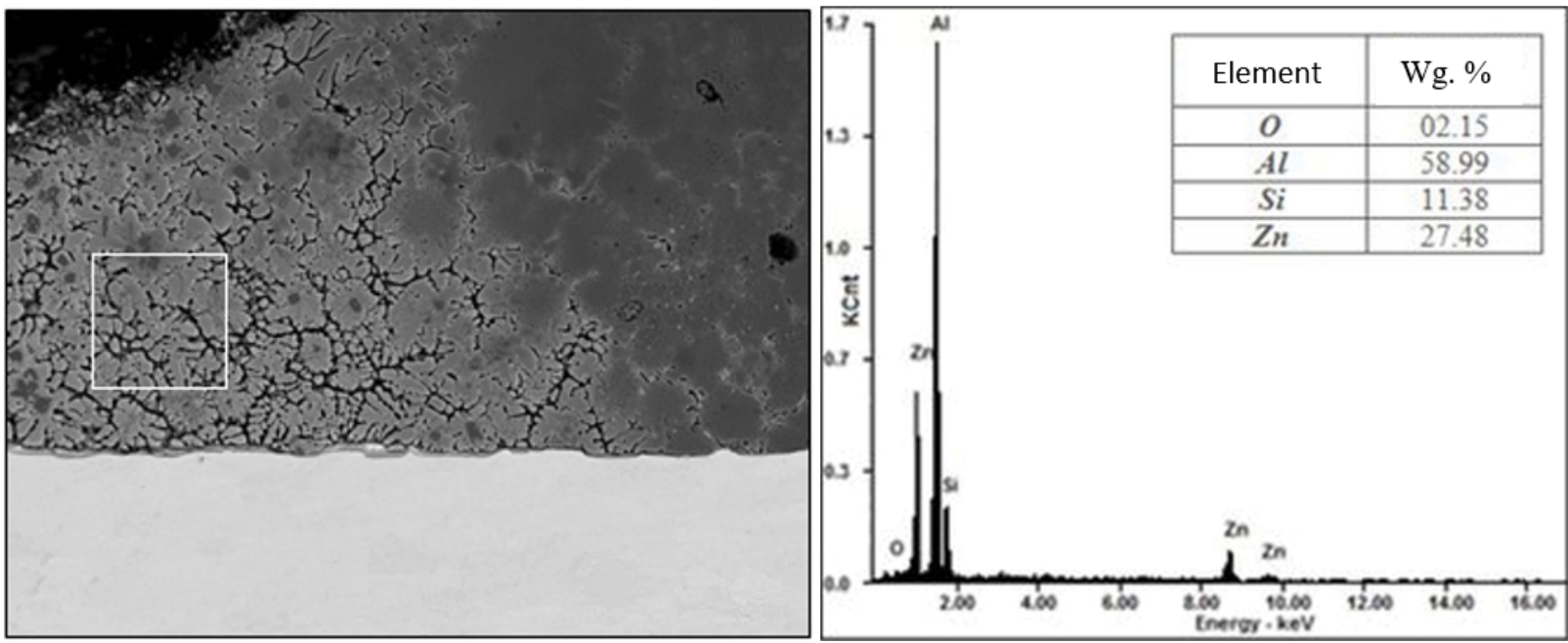

Fig. 10. BSE view of braze metal of lap joint aluminium grade 1050A - galvanized carbon steel DC04 CMT MIG-brazed with additional material in form of grade S Al 4047 solid wire (magn. 500×) and micro-analysis of chemical composition in test area located near steel plate surface
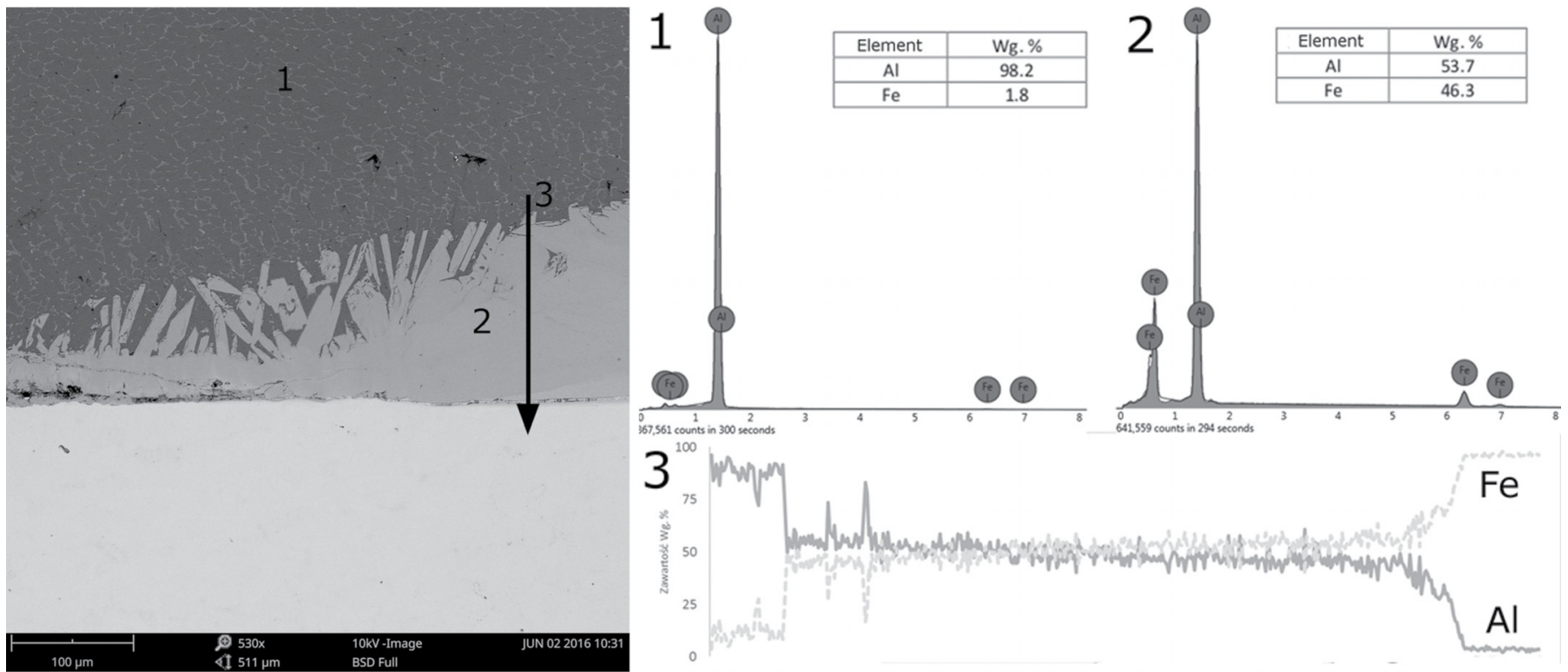

Fig. 11. BSE view of reactive layer in braze metal of lap joint aluminium grade 1050A - galvanized carbon steel DC04 braze-welded by high power diode laser with additional material in form of grade 1070A aluminium powder including EDS analyses placement and their results

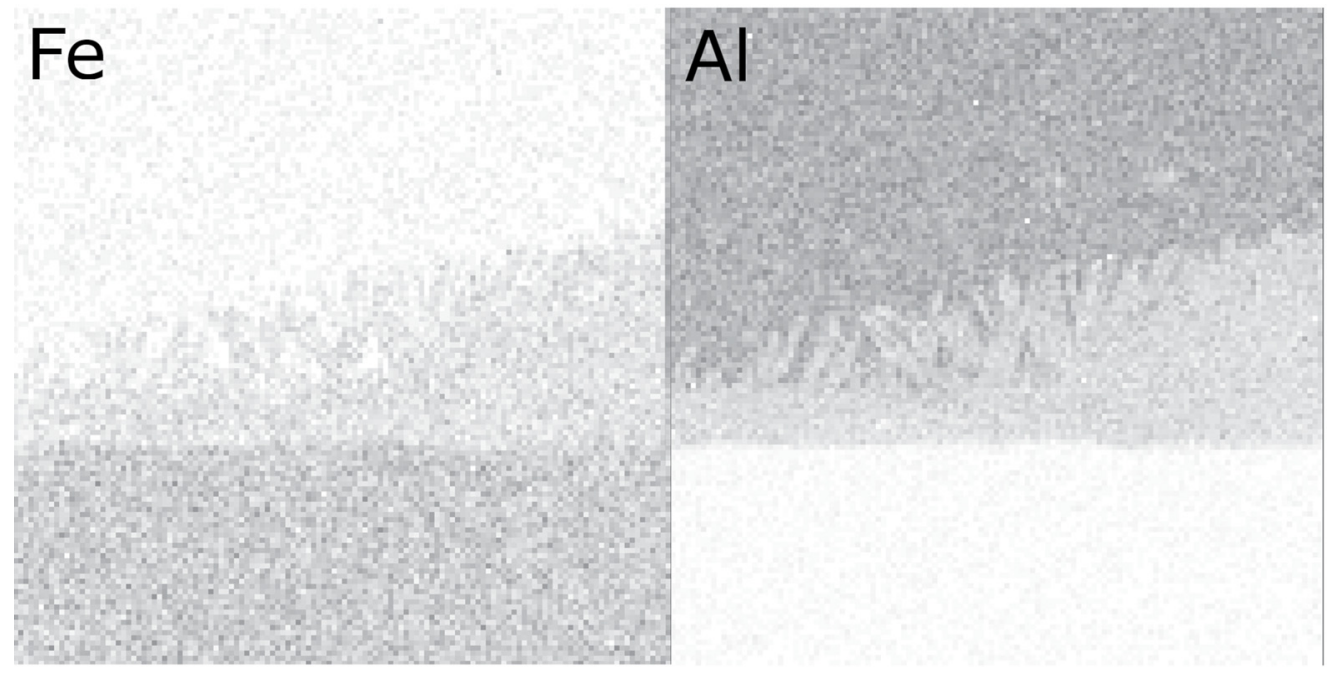

Fig. 12. Elemental maps of view form Fig. 11 for iron and aluminium 

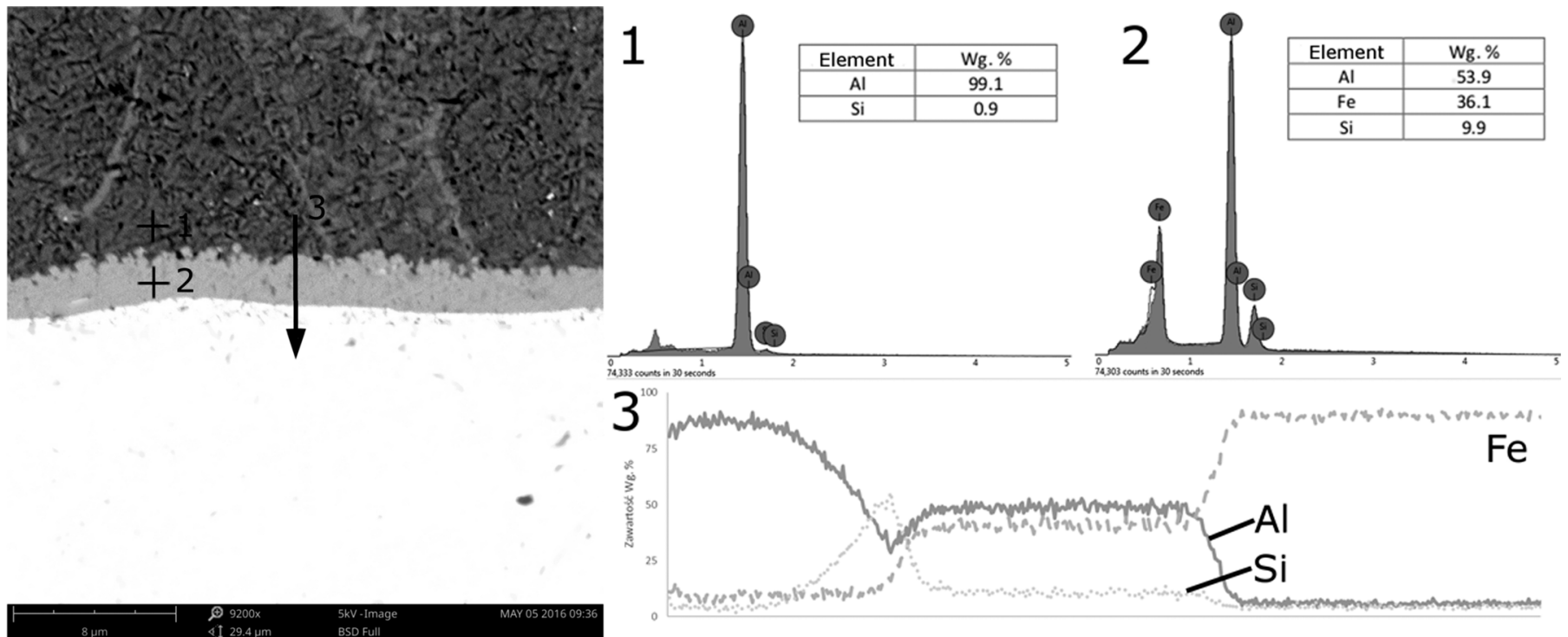

Fig. 13. BSE view of reactive layer in braze metal of lap joint aluminium grade 1050A - galvanized carbon steel DC04 CMT MIG-brazed with additional material in form of grade S Al 4047 solid wire including EDS analyses placement and their results

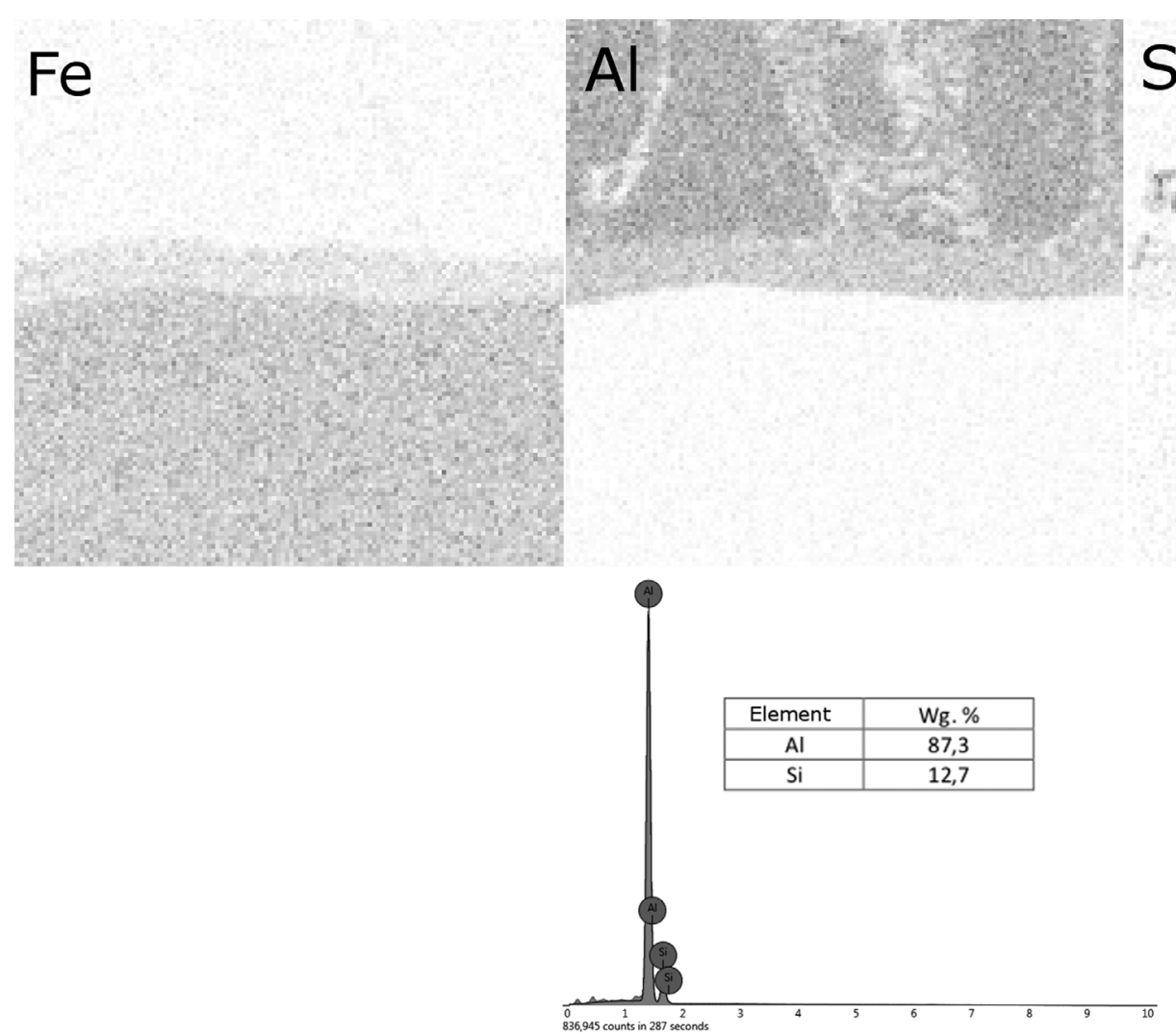

Fig. 14. Elemental maps of view form fig. 13 for iron, aluminium and silicon and results of chemical composition analysis in micro-area of braze metal adjacent to transition zone

metal elemental heat maps for Al, Fe and Si were produced. Also, chemical composition in rectangular filler metal area $30 \times 30 \mu \mathrm{m}$ adjacent to reactive layer was verified (Fig. 14). Elemental heat maps presented in Fig. 14 have shown that low silicon content in test point 1 , as well as, its increase on transition point from filler metal into reactive layer were caused by morphological heterogeneousness of filler metal structure. On border of filler metal and reactive layer both silicon-rich and silicon-sparse phases were present. EDS analysis results from wider area have shown silicon content of about $12 \%$ in filler metal, which matches composition of additional material in form of solid wire.

$\mathrm{X}$-Ray diffractometry was carried on aluminum - galvanized steel lap joints made with HPDL brazing and CMT MIGbrazing to identify phases present in filler metal and reactive layer. Results of X-ray qualitative phase analysis were presented on diffractograms (Figs. 15-16). 


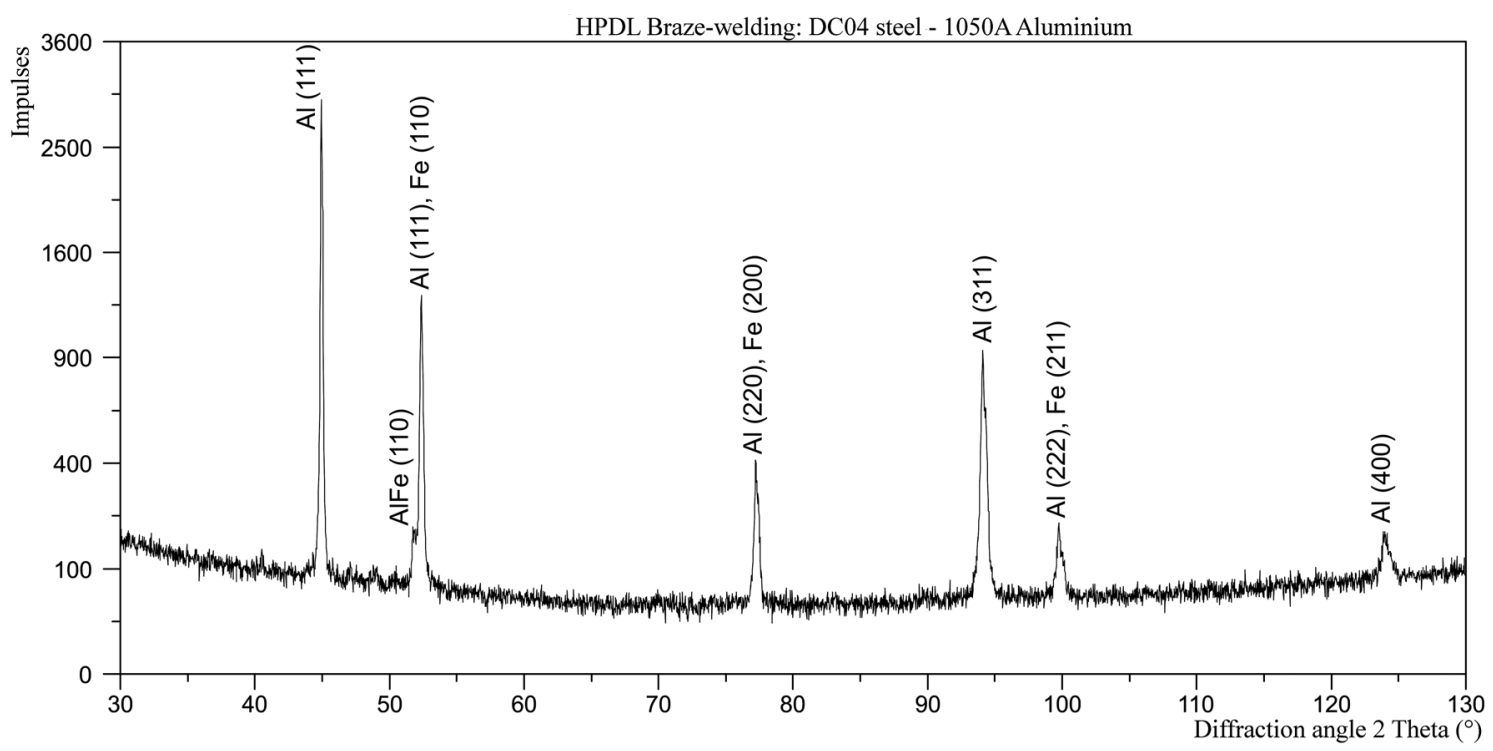

Fig. 15. Diffractogram from braze metal of lap joint aluminium grade 1050A - galvanized carbon steel DC04 braze-welded by high power diode laser with additional material in form of grade $1070 \mathrm{~A}$ aluminium powder

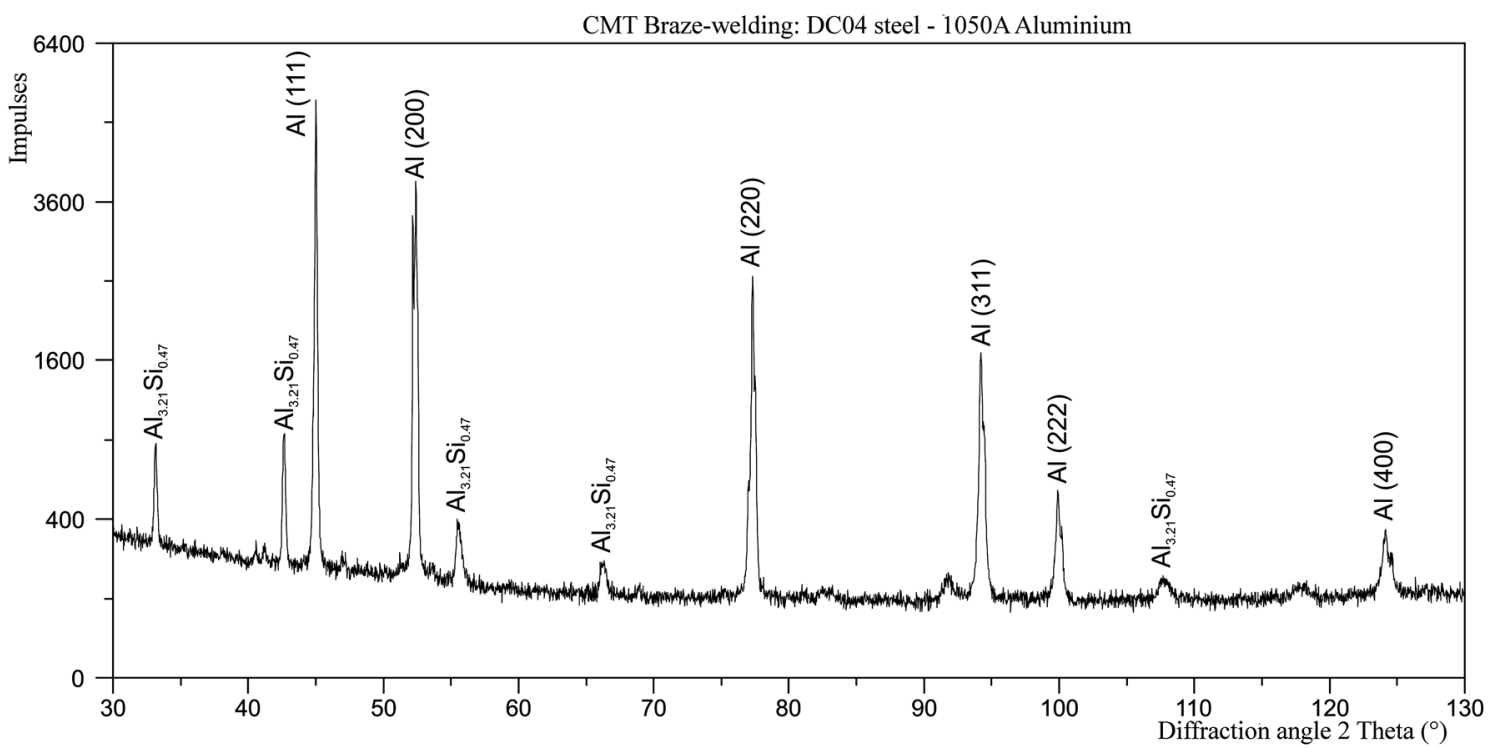

Fig. 16. Diffractogram from braze metal of lap joint aluminium grade 1050A - galvanized carbon steel DC04 CMT MIG-brazed with additional material in form of grade S Al 4047 solid wire

Diffractometry did not clearly confirm presence of Al-Fe intermetallic phases in braze-welded joints of aluminum grade 1050A and zinc plated steel DC04. In structure of HPDL brazewelded with additional material in form of aluminum grade 1070A powder joint, aside from presence of aluminum and iron phases, only small diffraction peak coming from plane (110) of $\mathrm{Al}-\mathrm{Fe}$ intermetallic lattice was observed. In structure of CMT braze-welded with additional material in form of aluminum grade $\mathrm{S}$ Al 4047 solid wire joint five diffraction peaks from $\mathrm{Al}_{3.21} \mathrm{Si}_{0.47}$ were observed.

Hardness tests were carried with Vickers method with load of $100 \mathrm{gf}$ (HV 0.1). Test points were placed on singular line traversing 3 distinctive joint parts: aluminum matrix base material, filler metal and carbon steel base material. Test points placement and microhardness test results for dissimilar alu- minum - galvanized steel joints brazed with laser and MIG were presented in Fig. 17.

Aluminum grade 1050A base material was characterized by hardness from $63 \mathrm{HV} 0.1$ to $72 \mathrm{HV}$ 0.1. In both CMT MIG-brazed joints and laser brazed joints, in result of reheating, tendency to hardness decrease in zone adjacent to filler metal (HAZ) was observed. Tested microareas of filler metal in braze-welded joint with additional material in form of aluminum grade 1070A powder were characterized by from $54 \mathrm{HV} 0.1$ to $62 \mathrm{HV} 0.1$, lower than hardness of aluminum alloy 1050A and hardness of filler metal in joints with additional material in form of aluminum grade S Al 4047 solid wire (87-91 HV 0.1). In carbon steel DC04 base material hardness in area near the edge of filler metal was, for laser brazed joint and CMT MIG-brazed joint, $133 \mathrm{HV} 0.1$ and $128 \mathrm{HV} 0.1$, respectively. This results confirm existence of 

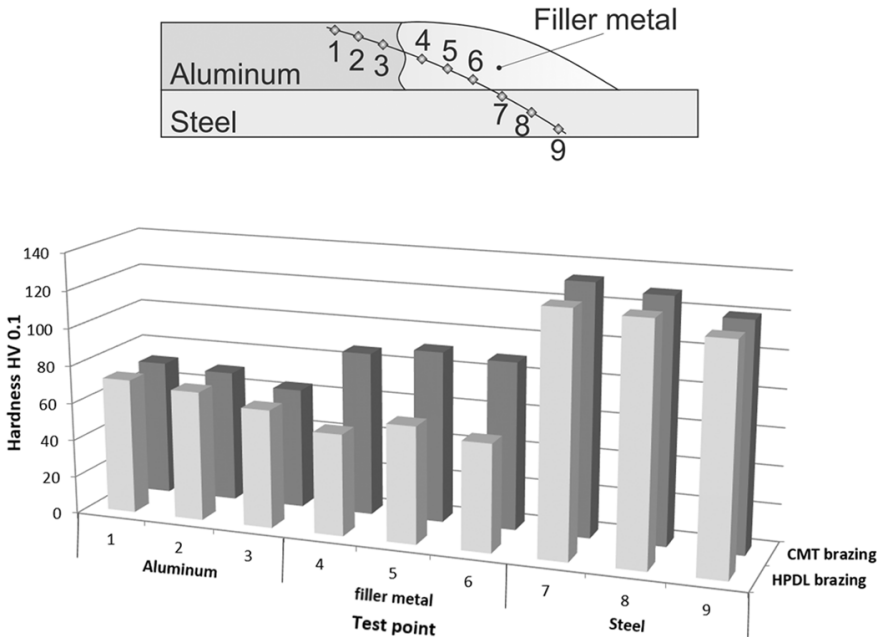

Fig. 17.

thin HAZ with lightly elevated hardness. Hardness of carbon steel plate $500 \mu \mathrm{m}$ from surface was around $120 \mathrm{HV} 0.1$, which is characteristic for ferritic structure with traces of perlite and cementite.

\section{Conclusion}

Braze-welding technologies of joining dissimilar materials in form of thin aluminum grade 1050A plates and plates from galvanized carbon steel DC04 with overlap, carried with use of high power diode laser and additional metal in from of Al 1070A alloy powder or CMT method with additional material in from of solid S Al 4047 wire, are characterized by process stability and enable formation of joints with correct geometry and without any defects detectable by visual testing. In optimal parameter range heat effects of both laser beam and electrical arc on backside of joint were unable to damage protective zinc layer in a degree decreasing anti-corrosion resistance of material. However, in case of joint made by powder HPDL-brazing, in contrast to joint made by CMT arc-brazing, internal structure was not free from defects in form of cracks and inclusions. Cracks in aluminum matrix filler metal were brittle in nature, caused by appearance of brittle intermetallic layers in transition phase between filler metal and steel plate. Iron, present in filler metal as a result of partial melting of steel plate, was dissolving in aluminum alloy of filler metal producing as a result brittle Al-Fe intermetallic phases in layer bordering steel plate, which decreased joint plasticity.

Stronger melting of steel plate and diverse crystallization conditions of filler metal in joint made by laser brazing in comparison to joint made by arc brazing were negatively affecting reactive layer structure, thickness, stress distribution and boding force with substrate. Reactive layer high thickness, fast cooling and strong convection in liquid filler metal in powder laser brazed joint favored increase in stress levels, in result cracks were propagating along transition surface reactive layer - steel plate and filler metal was separated from steel plate substrate.

During braze-welding by laser and arc heat sources zinc, used as anti-corrosion protective layer of carbon steel, was melted and partially vaporized. Low zinc solubility in $\alpha$ aluminum solid solution could cause zinc to appear in filler metal as oxide inclusion like $\mathrm{ZnO}, \mathrm{Al}_{2} \mathrm{O}_{4} \mathrm{Zn}$ or $\mathrm{Fe}_{2} \mathrm{O}_{4} \mathrm{Zn}$. Substantial amounts of melted zinc were moved by liquid filler metal into its sides. In CMT MIG-brazed joint zinc-rich area was located in outer border of filler metal and continuity of protective layer was retained. In HPDL brazed joints area with highest zinc content was located near inner edge of filler metal, additionally higher vaporization rates and faster crystallization, in comparison to arc-brazing, were promoting factors in formation of long gas pores, that often were crack initiators.

Formation of braze welded lap joint from aluminum and galvanized carbon steel of acceptable quality level requires strictly determined heat input, sufficient to melt additional material and heat up base material to bonding processes activation temperature, but small enough to prevent partial melting of steel plate.

\section{Acknowledgement}

This work was supported by the Ministry of Science and Higher Education of Poland as the statutory financial grant of the Faculty of Mechanical Engineering, Silesian University of Technology

\section{REFERENCES}

[1] W. Gawrysiuk, Biuletyn Instytutu Spawalnictwa 3, 35-40 (2005).

[2] M. Różański, W. Gawrysiuk, Przegląd Spawalnictwa 9, 7-12 (2007).

[3] W. Gawrysiuk, T. Pfeifer, A. Winiowski, Przegląd Spawalnictwa 2-3, 17-20 (2005).

[4] P. Białucki, A. Ambroziak, W. Derlukiewicz, A. Lange, T. Bednarek, Przegląd Spawalnictwa 9, 20-28 (2013).

[5] J. Matusiak, B. Czworonóg, T. Pfeifer, Biuletyn Instytutu Spawalnictwa 6, 41-46 (2007).

[6] M. De Dompablo, Przegląd Spawalnictwa 7-8, $12-17$ (2009).

[7] M. Różański, Przegląd Spawalnictwa 9, 24-28 (2010).

[8] A. Zieliński, G. Golański, M. Sroka, Mat. Sci. Eng. A-Struct. 682, 664-672 (2017).

[9] M. Sroka, A. Zieliński, M. Dziuba-Kałuża, M. Kremzer, M. Macek, A. Jasiński, Metals 7 (3), 82 (2017). 